\title{
FLEXIBLE FORMS OF EMPLOYMENT IN POLAND ON THE EXAMPLE OF WORKING PHONE
}

\begin{abstract}
Today's labor market "requires" from human resources flexibility, mobility, retraining, because technological novelties, the Internet are changing irretrievably the environment in which we are employed. In the Polish labor market the development of certain "trends" in the context of the employment, which may lead to a significant reduction of the traditional work model can be observed .

The aim of this study is to evaluate telework as one of the possibilities of a flexible form of employment in the aspect of the development of the labor market in Poland. The article uses the data of the Central Statistical Office and the PBS DGA poll, commissioned by "Gazeta Prawna" and CMS Cameron McKenna, concerning employment and working at a distance. The considerations undertaken allowed to indicate the advantages and disadvantages of teleworking and to indicate the main recipients of this form of employment.
\end{abstract}

Keywords: flexible forms of employment, phonework.

\section{INTRODUCTION}

Modern work is saturated with knowledge and technology, thanks to which individuals and organizations can actively participate in global competition. The consequence of this situation is the need to learn about new forms of work in changing conditions, about innovations and projects that are implemented in organizations (https://www.czasopismologistyka.pl/artykuly-naukowe/send/305-artykuly-na-plycie-cd-4/5069-artykul).

Today's labor market "requires" from human resources flexibility, mobility, retraining, because technological novelties, the Internet are changing irretrievably the environment in which we are employed. On the Polish labor market can be observed the development of certain "trends" in the context of the employment, which may lead to a significant reduction of the traditional work model.

It is more and more popular the convictions that flexible employment is one of the solutions when the economics slow down. Nowadays the growing phenomenon of non-employment employment, constituting a flexible form of employment can be observed very often. It is based on employment on a different basis than the employment relationship (www.KRYTYKA.org).

The aim of this study is to evaluate phonework as one of the possibilities of a flexible form of employment in the aspect of the development of the labor market in Poland. The

\footnotetext{
${ }^{1}$ Katarzyna Puchalska, PhD Eng., Department of Macroeconomics and International Relations, Faculty of Economics, University of Rzeszów, ul. Ćwiklińskiej 2, 35-601 Rzeszów; e-mail: k_puch@ur.edu.pl. ORCID: 0000-0002-3924-8447.
} 
article uses the data of the Central Statistical Office and the PBS DGA poll, commissioned by "Gazeta Prawna" and CMS Cameron Mc Kenn, concerning employment and working at a distance.

\section{THE LABOR MARKET IN POLAND}

„The labor market is the general forms and processes of employing employees by employers, as well as total of institutions, conditions and factors of negotiations, terms of employment, work and pay; economic, social and political area where all processes of broadly understood employment and unemployment take place" (Lexicon PWN, online) It covers the whole of issues related to shaping labor supply and demand. Diversification of labor supply and demand results in the formation of relatively closed for labor force flow market segments. Limited access to certain parts of the labor market may be caused, among others, by specific requirements of employers that disqualify a specific part of employees; factors created artificially by, for example, exclusion from employment opportunities for people who are not members of a given trade union organization; cultural factors, moral and other obstacles impossible to overcome by a potential employee.

In Poland, the number of professionally active people in the second quarter of 2018 amounted to 17,182 thousand, and it was by 129 thousand (0.8\%) higher in relation to the results of the first quarter of 2018 and by 177 thousand. (0.6\%) to the second quarter of 2017 (according to Central Statistical Office data). In turn, the number of economically inactive people in the second quarter of 2018 was estimated at 13246 thousand. So it fell by 159 thousand. (1.2\%) in relation to the first quarter of 2017 and by $8,000(0.1 \%)$ in relation to the second quarter of 2017. From a longer period (according to the Central Statistical Office), the professionally active group is relatively stable and oscillates around 17 million. Meanwhile, the number of economically inactive people increased from 1993 to 2007, increasing from 11 million to 14.7 million. In recent years, however, it started to decrease slightly and since mid-2011 it does not exceed 14 million, and the result recorded in mid-2017 was the lowest since 2001.

The increase in the number of professionally inactive people by nearly $1 / 3$ can be explained primarily by the aging of the population - the demographic boom has entered in the labor market a few years ago, ensuring generational renewal, but the prolonged life expectancy extends the period of retirement, i.e. inactive (for most pensioners). The low level of pensions and disability, however, has prompted many older Poles to look for their place in the market - hence probably stopping the growth of the number of professionally inactive people recently.

1/4 of employees in Poland have the possibility of working remotely in their company, for example from home. This is the domain of companies from cities with more than 200,000 inhabitants (32\%), and such solutions are used mainly by senior managers (52\%) and middle managers (38\%) and specialists (37\%). Remote work is the most common solution among self-employed workers (54\%) and employed on civil law contracts (32\%).

Specialists from the Adecco Personnel Advisory Agency emphasize that the labor market in Poland in 2018 is struggling with the growing problem of mismatch between educational programs and the needs of the economy. This is despite the fact that Polish universities educate the most future CEO (Chief Executive Officer) in the region. According to the report "Competences of the future - the fourth industrial revolution in Eastern Europe", it can be considered that the economy suffers especially due to deficits related to the "com- 
petences of the future". According to Adecco experts, in Eastern Europe, the hard competences sought will include, among others: strategic management in IT, mechanical engineering, aeronautical engineering, search engine positioning (SEO), cyber security, data analytics. Unfortunately, it is impossible to correlate the requirements of the labor market with the curriculum, when the competences sought can only be revealed after graduation (https://bezprawnik.pl/rynek-pracy-w-polsce-w-2018).

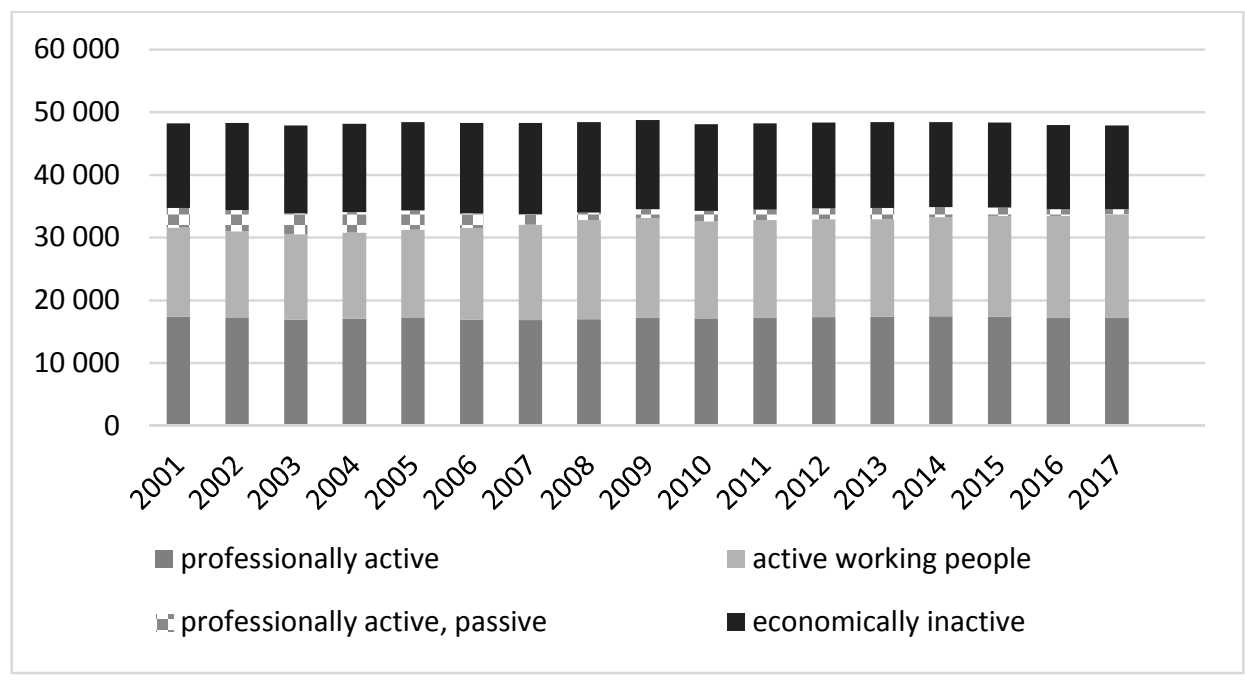

Fig. 1. Active and professionally inactive in Poland in the years 20012017 (in thousands of people)

Source: prepared on the basis of CSO data.

\section{FLEXIBLE FORMS OF EMPLOYMENT}

Flexible forms of employment mainly include unusual employment relationships. In this range, the work is primarily unstable, often performed outside the company and part-time, work for a trial period or on a call. Such employment results in limited rights to social and employment benefits. Flexible forms of employment concern both employment for employees regulated by the Labor Code and non-employment employment, the legal basis of which is the Civil Code (Gębski, 2014).

The types of flexible forms of work can be divided into three groups:

- forms of employee employment - this group includes: term contracts, part-time work, temporary work, teleworking, work on call, Job sharing.

- Forms of non-employment employment - in turn, this group includes: civil law and employment contracts.

- Other forms of employment - such as: Job rotation, outsourcing, self-employment (collective work 2010).

Seeking the features justifying the nature of unusual employment, which play a significant role in the modern market economy - one can notice growing competition in many dimensions, including employment in domestic and international enterprises, intensification 
of the flow of production (work) factors. Unusual forms of employment can be stimulated by the intellectualization of participants in the manufacturing process, resulting from permanent and lifelong learning - which favors and drives the use of atypical forms of work and an increase in the demand for work performed on a variable time basis (Gębski, 2014).

The flexible way of employment supports pupils, students as well as women bringing up children both due to the premises related to the family situation, as well as in relation to internal motivation - the need for development and professional fulfillment. He also serves specialists and representatives of free professions. Examples of flexible forms of employment include: teleworking, which, thanks to the use of information technology, enables the employee to perform activities at a distance. However, to fulfill professional tasks in this way, one condition must be met. Both the employer and the employee must express their readiness to use the given form of employment. The employer's readiness should be primarily justified by the type, organization or place of work. In the case of an employee deciding to take up this form of employment, his internal motivations are the most important.

\section{TELEWORK AS AN EXAMPLE OF A FLEXIBLE FORM OF EMPLOYMENT}

Telework is a modern method of work, because thanks to the latest information and communication technologies, it enables the employee to perform activities resulting from the employment relationship at a distance. In this way, the employer acquires an employee whose knowledge, competences and skills are valuable to him, and for various reasons he is unable to work at the company's headquarters. Such persons include, above all, people with disabilities or women who deal with home and children. In view of the above, such a form of employment becomes a chance for these people to exercise their profession and take up employment. Teleworking provides an additional opportunity to take up employment by people who are in a special situation, encountering various restrictions that disqualify them to perform work in a traditional form at the company's headquarters, expressing willingness and being able to cope with obligations arising from the employment relationship, working, for example, in their residence and using modern ICT tools for this purpose (Karbownik, 2017).

The European Commission defines telework as a method of organizing and performing work, where the employee works for a part of his working time outside the enterprise employing him, thereby providing the employer with the results (so-called results) of work using information technology as well as data transfer technologies, especially the Internet (Janiec, Czerniak, Kreft, Piontek, 2006). The definition of the EC draws attention to the organizational aspect of teleworking, moreover, it indicates the fact that the employee performs his duties outside the workplace (Karbownik, 2017).

Telework is a relatively new form in the Polish work system (it has been in operation since 2007).

According to art. 675 of the Labor Code, teleworking is a job regularly performed outside the workplace by using electronic means of communication within the meaning of the provisions on the provision of electronic services. When working, the parties agree on a place of work that is most convenient for both the employee and the employer. This is an issue important enough because it determines the type of teleworking. The purpose of teleworking is to increase the flexibility of work (Armstrong, 2000). Teleworking also contributes to a significant reduction in labor costs (Armstrong, 2000). 
The main advantage of this form of work is the ability to perform directly from home (which usually allows for flexible working time and combining work with family life), low wages and job insecurity are considered the basic disadvantage.

The main barrier to teleworking is:

- not signing employment contracts by employers - as a result, employees lack the sense of security, ensure regular income;

- limited job offer - only low-paid, uninteresting, not prestigious jobs are available;

- employers consider employees to be inferior, do not trust them and therefore do not sign contracts with employees, sometimes try to cheat them - they do not pay or very much delay the payment of employees' debts;

- big fear of loss of interpersonal contacts, before social isolation, fear of a new one, accustom to the traditional method of working in the employer's office, which is perceived as more "natural" than the teleworking method.

In the opinion of some employers, the most serious obstacles to the development of telework are:

- lack of trust in the employee with whom the employer contacts sporadically, over which the work process has only limited control;

- avoiding signing a contract of employment due to the willingness to reduce labor costs and the aforementioned lack of trust.

This relatively new form of employment has the following types:

- home teleworking (home-based teleworking) - the most common type of telework, carried out at home or in a telework apartment;

- interchangeable telework - partial work in the office and at home, eg work done for 3 days at home, the rest in the office.

As part of tele-work provided outside the workplace and outside the home, we distinguish:

- teleworking provided in the telecentre (teleworking form remote offices) - these are points away from the company, the office room can be either the property of the employer or another entity that operates the call center as part of the business activity;

- mobile teleworking (mobile telework) - a characteristic feature is the performance of work outside the company's office, just in the place where the teleworker is located, thanks to the use of teleinformation techniques, this form is mainly intended for people moving most of the time;

- telecottage - it is nothing else than a telecentre transferred to rural areas, for this purpose the most unused school, utility rooms, or in specially prepared for this purpose rural huts, are intended to increase the professional qualifications for people, that do not have access to companies located in urbanized cities.

The time range of teleworking can vary, i.e. it can be done both full-time and part-time, which gives the employee and the performer more flexibility and is a beneficial solution for disabled people and parents taking care of children.

The poll PBS DGA, commissioned by "Gazeta Prawna" and CMS Cameron McKenna, concerning employment and working at a distance, showed that in the consciousness of the average Pole, teleworking is not a known concept. The study was carried out on October 26-28, 2007 on a representative 1048-person group of Poles over 18 years of age. It was carried out in the CAPI (Computer Assisted Personal Interview) technique, ie a direct computer-assisted questionnaire interview, as part of the Omnibus survey, carried out every two 
weeks by PBS DGA Almost 40 percent respondents who were presented with the definition of telework declared that they had never heard of such a form of employment. The survey also showed that the percentage of people who did not meet with this form of employment increases with age. Among young people, up to 39 years old, it is less than 30 percent, and in the oldest age group over 50 percent. Knowledge of the basic issues related to telework is more common among people who, because of their education or professional position, can be a group of potential teleworkers or telecomers. Among respondents with higher education and representatives of the managerial staff, only one in eight respondents did not hear about teleworking. The study proved that those who, because of their place of residence could benefit the most, would know the least about the possibilities of such a form of work - people from rural areas (48\% of respondents said they did not know the concept of telework) 14. Almost 90 percent Polish employees think that they would not be able to perform their current job in the form of telework, and only every fifty employed without reservation would agree to perform their duties remotely. The opportunity to work at home seems particularly attractive for people who want to reconcile family responsibilities with a professional career. For this reason, the results clearly indicate that teleworking would be more likely to take unemployed women (84\%) than non-working men (66\%) (http://www.e-mentor.edu.pl/artykul/index/numer/30/id/662).

Based on the above figure 2 , it can be concluded that teleworking works as a form of employment, especially in services. Particularly noteworthy is the IT industry, in which a telework share of $15.6 \%$ of the total number of employees was recorded. In addition, the high telecommuting ratio is characterized by creative work (research, analysis, projects) and marketing activities. Telework is used at a similar level (4.3\% on average) also in enterprises dealing in trade and real estate services.

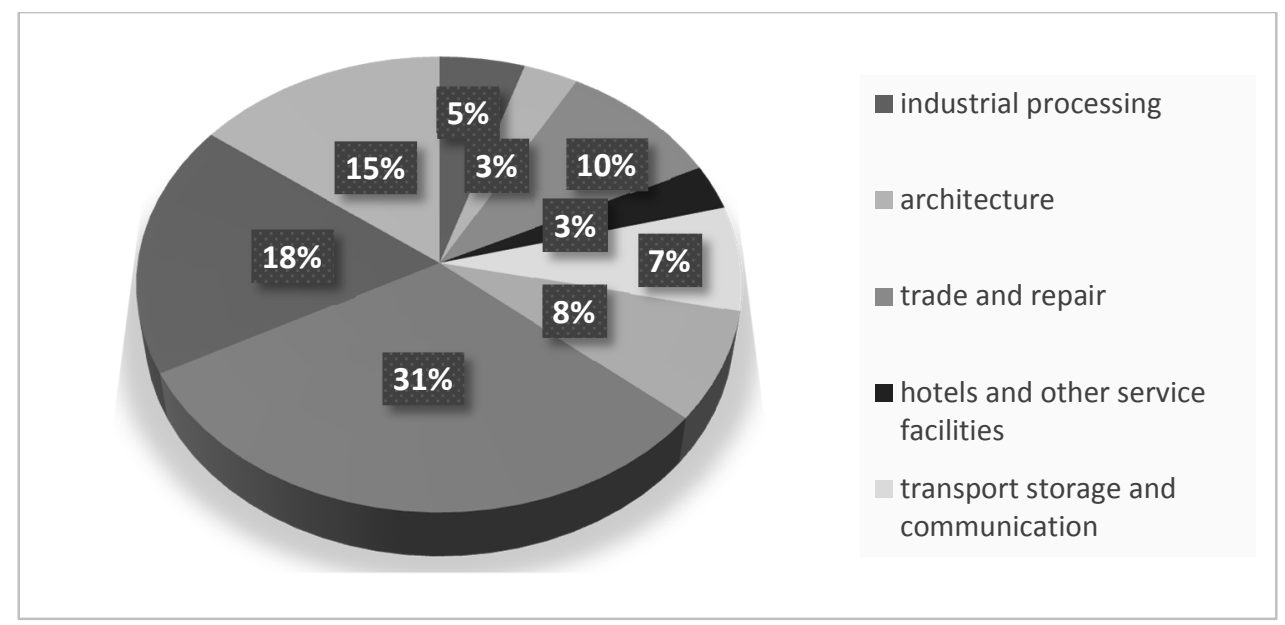

Fig. 2. Enterprises* employing teleworkers in Poland according to selected types of economic activity in 2008 .

* without enterprises engaged in financial intermediation

Source: data developed by (Sedlak \& Sedlak-www. wynagrodzenia.pl). 


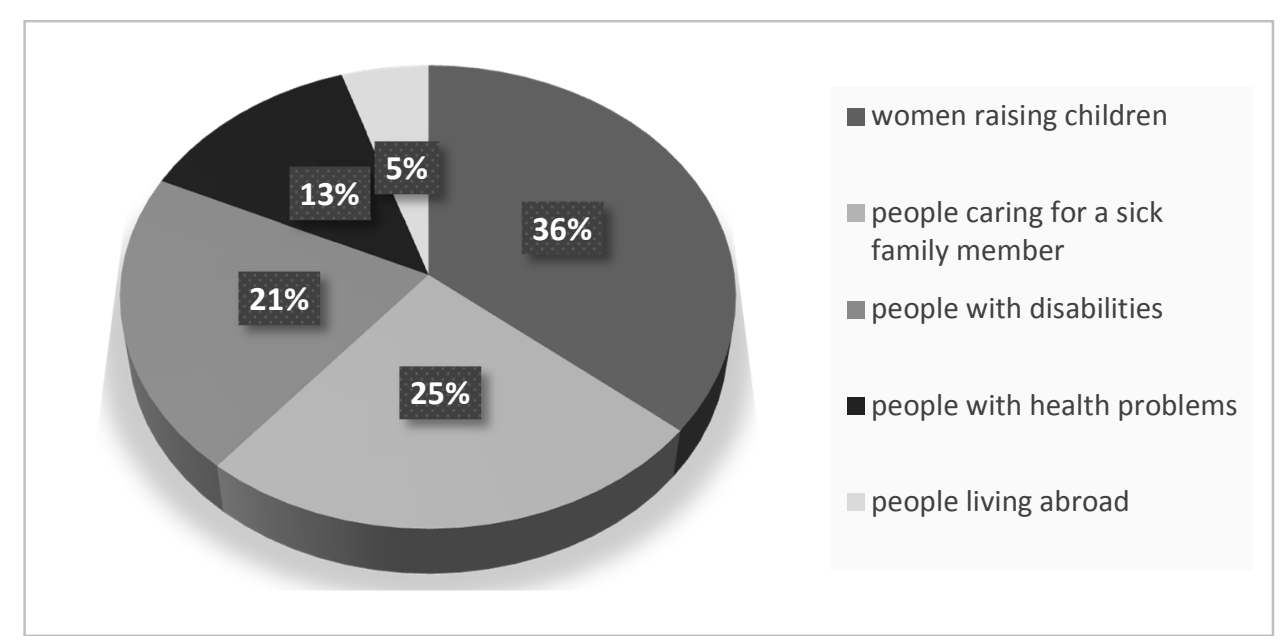

Fig. 3. People working mainly in telework (\% of people from a given group)

Source: prepared on the basis of (Karbownik, 2017).

According to K. Karbownik, who analyzed data from 145 representatives of the management, the largest group among teleworkers are women who raise small children $36 \%$ ). The second place was taken by people caring for ill members of the family $(25 \%)$ who have to take their duties towards the employer with care for relatives who need their permanent presence (fig. 3).

\section{CONCLUSIONS}

Teleworking is a method of employment that allows not only to reduce the company's fixed costs, but also to hire employees. Despite the legal regulations and increasing use of modern ICT and telecommunications technologies, the employment model in the form of telework is still not very popular form of employment in Poland. In 2016, in this way 4.6 percent worked. total number of employees. Advanced technology means that teleworking can be the future. Employers, however, cautiously approach this form of employment, primarily due to a number of formal conditions to be met (https://biznes.newseria.pl/news/niecale-5-proc, p20870570).

This form of employment is more often taken by women than men - especially those taking care of young children. In addition, this form of work is also a good solution for pregnant women who, taking into account the benefits of less formal working time of the teleworker, may design from the transition to medical exemption and may also be an alternative to childcare leave. It is also a great opportunity for people with disabilities to provide work. Working at home also limits the use of sick leave during minor ailments, the employee is not exposed to commuting and inconvenience connected with it, so he is also less willing to use these forms of absence from work. Benefits for the employer are obvious there is no need to provide replacement for such an employee, so the employer avoids the costs of recruitment, training or subsequent implementation of a new employee (https:// e-prawopracy.pl/telepraca/). Certainly the biggest advantage of teleworking is the ability to 
perform directly from home (which usually allows for flexible working time and combining work and family life).

The employer also has a much greater opportunity to recruit specialists from outside the city in which he is based. The employment of specialists, especially about niche qualifications, translates into improved competitiveness and profitability of the business.

The low salary and insecurity of employment are considered to be the biggest disadvantage of this form of work.

\section{REFERENCES}

Armstrong, M. (2000). Zarządzanie zasobami ludzkimi. Kraków: Oficyna Ekonomiczna.

Gębski, M. (2014). Elastyczne formy zatrudnienia w realiach rynku pracy. „Studia i Materiaty. Miscellanea Oeconomicae”, $\mathrm{nr}$ 3/2014.

https://www.czasopismologistyka.pl/artykuly-naukowe/send/305-artykuly-na-plycie-cd4/5069-artykul [Access: 7.11.2018].

http://www.egospodarka.p1/150036,Monitor-Rynku-Pracy-II-kw-2018-r,1,39,1.html [Access: 7.11.2018].

https://bezprawnik.pl/rynek-pracy-w-polsce-w-2018/ [Access: 4.11.2018].

http://www.e-mentor.edu.pl/artykul/index/numer/30/id/662 [Access: 7.11.2018].

https://biznes.newseria.pl/news/niecale-5-proc,p20870570 [Access: 7.11.2018].

Janiec, M., Czerniak, T., Kreft, W., Piontek, R. (2006). Prowadzenie działalności biznesowej z wykorzystaniem telepracy. Warszawa: Polska Agencja Rozwoju Przedsiębiorczości.

Karbownik, K. (2017). Optymalizacja organizacji pracy w przedsiębiorstwie na przykładzie telepracy. Zeszyty Naukowe Politechniki Czestochowskiej Zarzadzanie, nr 25, t. 1/2017.

Krukowski, K., Oliński, M. (2010). Flexicurity w teorii i praktyce. Olsztyn: Fundacja „Wspieranie i Promocja Przedsiębiorczości na Warmii i Mazurach".

Organiściak-Krzykowska, A., Walkowiak, R., Nyklewicz, K. (2014). Innowacyjne formy pracy. Olsztyn: EXPOL.

Stanik, Z. (2010). Telepracownik zmniejsza koszty firmy o 30 proc. „Dziennik Gazeta Prawna”, 29 grudnia 2010.

Stownik $P W N$ on-line.

www.KRYTYKA.org

DOI: 10.7862/rz.2019.hss.29

The text was submitted to the editorial office: April 2019.

The text was accepted for publication: September 2019. 